ENGINEERING CHANGE NOTICE

\section{ECN 605027}

Page 1 of 2 Proj.

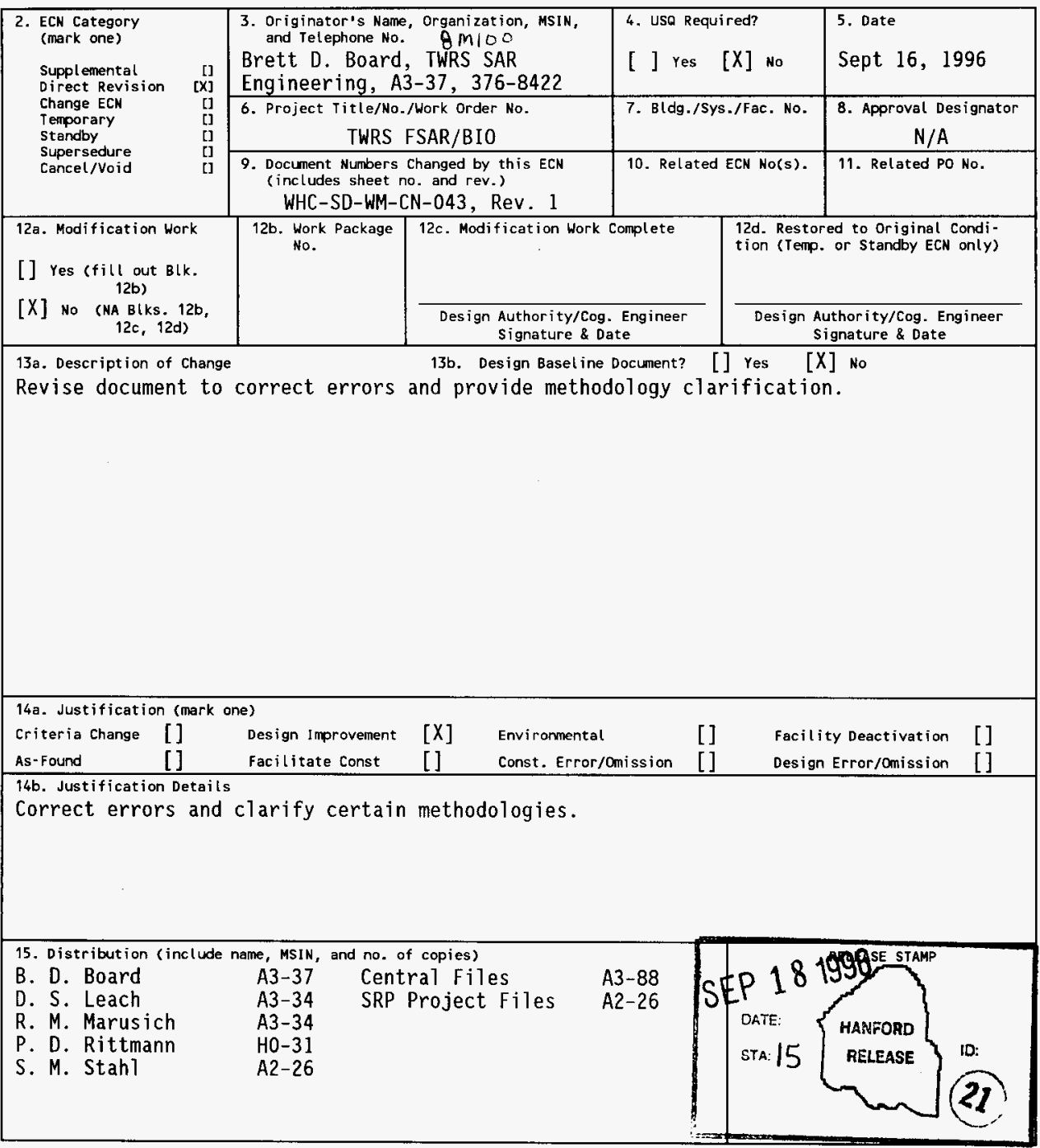

A-7900-013-2 (05/96) GEF095 


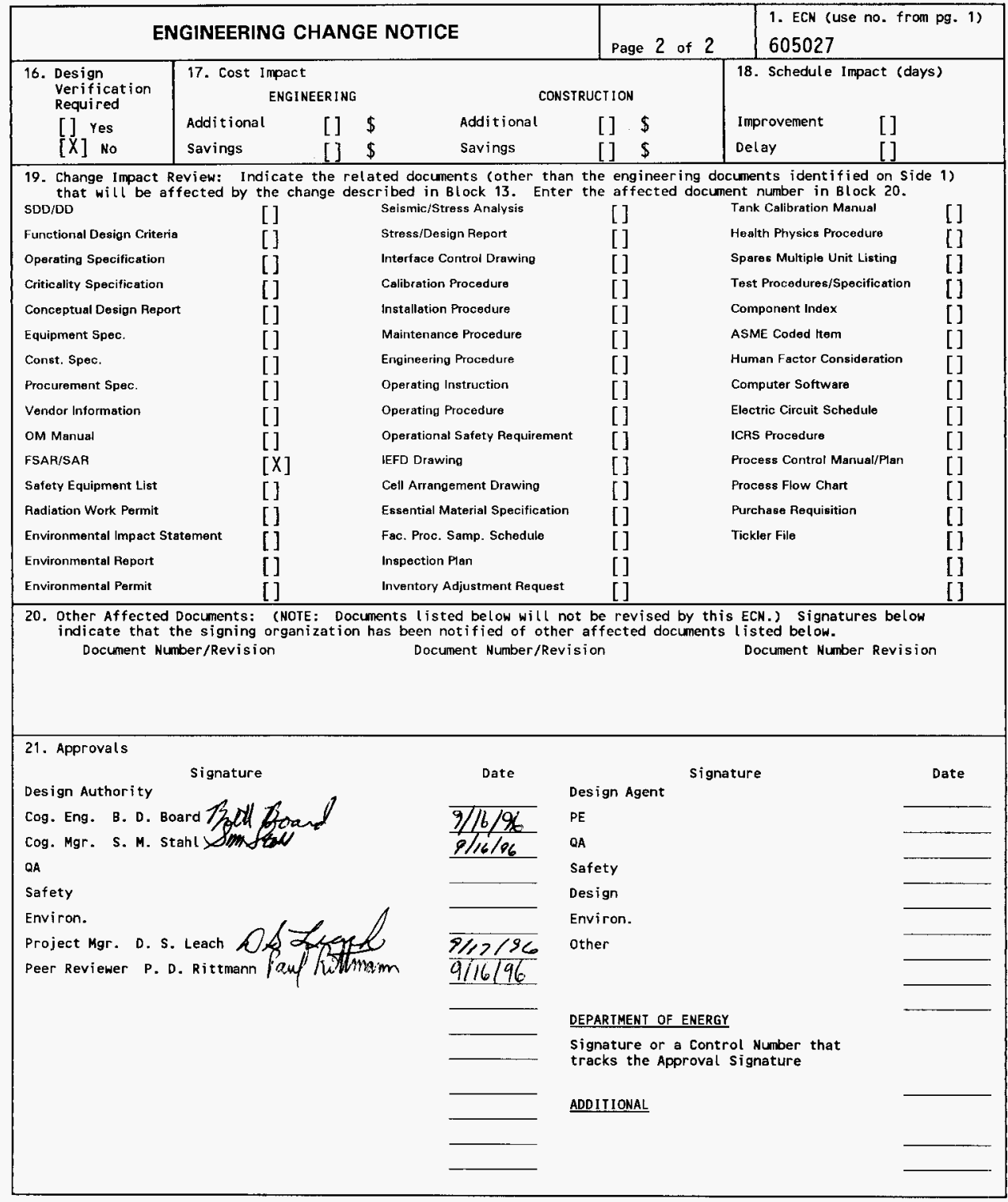




\title{
TANK BUMP CONSEQUENCE ANALYSIS
}

\author{
Brett D. Board \\ Westinghouse Hanford Company \\ Richland, WA 99352 \\ U.S. Department of Energy Contract DE-AC06-87RL10930 \\ EDT/ECN: 605027 \\ UC: 510 \\ Org Code: $8 \mathrm{Ml} 100$ \\ B\&R Code: EW3120071 \\ Charge Code: N1FC3 \\ Total Pages: 21
}

Key Words: bump, radiological, toxicological, consequence, thermal rollover, heat up, temperature, GOTH ${ }^{1}$, tank farm, FSAR, cover block decontamination factor

Abstract: The purpose of this document is to derive radiological and toxicological consequences for a tank bump event based on analys is performed using the GOTH ${ }^{1}$ computer model, to estimate the mitigative effect of pump and sluice pit cover blocks, and to discuss preventative measures.

${ }^{1}$ GOTH is a trademark of JMI, which is derived from GOTHIC - a registered trademark of the EPRI Corp. of California.

TRADEMARK DISCLAIMER. Reference herein to any specific commercial product, process, or service by trade name, trademark, manufacturer, or otherwise, does not necessarily constitute or imply its endorsement, recommendation, or favoring by the United States Government or any agency thereof or its contractors or subcontractors.

Printed in the United States of America. To obtain copies of this document, contact: HHC/BCS Document Control Services, P.O. Box 1970, Mailstop H6-08, Richland WA 99352, Phone (509) 372-2420; Fax (509) 376-4989.
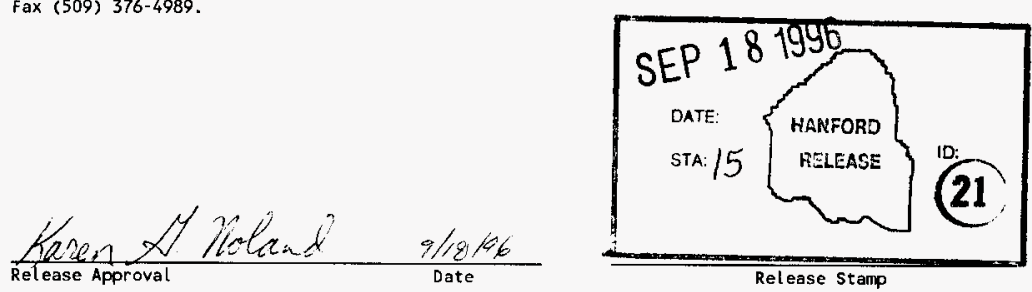
(2) Title

TANK BUMP CONSEQUENCE ANALYSIS

CHANGE CONTROL RECORD

\begin{tabular}{|c|c|c|c|}
\hline \multirow{2}{*}{$\begin{array}{l}\text { Revision } \\
0\end{array}$} & \multirow{2}{*}{$\begin{array}{l}\text { (4) Description of Change - Replace, Add, and Delete Pages } \\
\text { ED T-614548 }\end{array}$} & \multicolumn{2}{|c|}{ Authorized for Release } \\
\hline & & (5) Cog. Engr. & (6) $\mathrm{Cog} . \mathrm{Mgr}$. \\
\hline 1 & $\begin{array}{l}\text { (7) Revise analysis, complete revision per } \\
\text { ECN } \# 605029\end{array}$ & B. D. Board & S. M. Stah] \\
\hline${ }^{2} \mathrm{RS}$ & $\begin{array}{l}\text { Correct errors, clarify method, complete } \\
\text { revision per ECN } \# 605027\end{array}$ & Bat Board & S. Mestahl \\
\hline & & & \\
\hline & & & \\
\hline & & & \\
\hline & & & \\
\hline & & & \\
\hline & & & \\
\hline & & & \\
\hline & & & \\
\hline & & & \\
\hline & & & \\
\hline & & & \\
\hline & & & \\
\hline & & & \\
\hline & & & \\
\hline & & & \\
\hline & & & \\
\hline & & & \\
\hline & & & \\
\hline & & & \\
\hline & & & \\
\hline & & & \\
\hline & & & \\
\hline & & & \\
\hline & & & \\
\hline & & & \\
\hline & & & \\
\hline & & & \\
\hline & & & \\
\hline & & & \\
\hline
\end{tabular}


WHC-SD-WM-CN-043, Rev. 2

\title{
TANK BUMP CONSEQUENCE ANALYSIS
}

\author{
Brett D. Board \\ Westinghouse Hanford Company \\ Richland, Washington \\ September 1996
}


WHC-SD-WM-CN-043, Rev. 2

Table of Contents

1.0 PURPOSE . . . . . . . . . . . . . . . . . . 4

2.0 METHODOLOGY ..................... 4

3.0 ASSUMPTIONS ............................. . . 4

3.1 Tank Waste . . . . . . . . . . . . . . . . . . 4

3.2 GOTH Model . . . . . . . . . . . . . . . . . . 5

3.3 Mitigation .................... 6

3.4 Accident Frequency ............... . . 6

4.0 INPUT DATA .......................... 6

5.0 CALCULATIONS ........................ 7

5.1 Unmitigated Consequences .............. . 7 5.1.1 Radiological . . . . . . . . . . . . . . . . . . . . 7

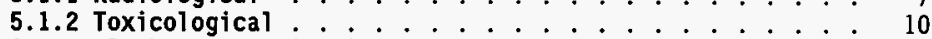

5.2 Cover Block Decontamination Factor . . . . . . . 10

5.3 Mitigated Consequences ................ 12

5.3.1 Radiological .................... . . 12

5.3.2 Toxicological ................... . . . 12

5.4 Rate of Temperature Rise ............... 13

6.0 RESULTS . . . . . . . . . . . . . . . .... 15

6.1 Consequences . . . . . . . . . . . . . . . 15

6.2 SST Temperature Limit . . . . . . . . . . . . . . . . . . . . 15

6.3 DST Temperature Limits . . . . . . . . . . . . . 15

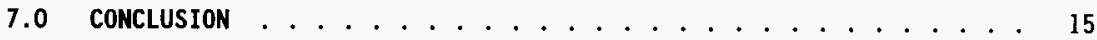

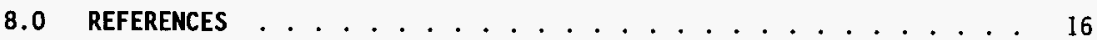

APPENDIX A - Decontamination Factor Calculations . . . . . . . . 17 
WHC-SD-WM-CN-043, Rev. 2

\section{List of Tables}

Table 1. Tank 101-AZ Waste Parameters ... . . . . . . . . . 5

Table 2. Waste Released by GOTH Model .............. 6

Table 3. Unmitigated Radiological Consequences. . . . . . . . . . . . 10

Table 4. Unmitigated Toxicological Consequences ........... 11

Table 5. Mitigated Radiological Consequences. . . . . . . . . . . . 13

Table 6. Mitigated Toxicological Consequences .......... 13

Table 7. Rate of Temperature Rise For Selected Single-Shell Tanks . . . 14

Table 8. Comparison of Consequences to Risk Guidelines. . . . . . . 15 
WHC-SD-WM-CN-043, Rev. 2

TANK BUMP CONSEQUENCE ANALYSIS

A tank waste thermal rollover phenomenon, commonly known as a tank bump, is a rapid steam pressurization of the tank headspace. Tank bumps have been recorded in the past and some have led to undesirable radioactive contamination to the surrounding area.

\subsection{PURPOSE}

The purpose of this document is to derive radiological and toxicological consequences for a tank bump event based on analysis performed using the GOTH computer model (Sathya 1996), to estimate the-mitigative effect pum and stute pit covep blocks, and to discuss preventative-measures and to discuss issues important to controlling tank bumps.

\subsection{METHODOLOGY}

This tank bump analysis is performed on waste tank 241-AZ-101 in the Aging Waste Facility (AWF) because it contains the highest heat load of all tanks and is, therefore, the most likely candidate for a tank bump. In addition, the radionuclide content in AWF solids is bounding for ail waste types.

Radiological and toxicological consequences are calculated with the methodology developed for use in the Tank Waste Remediation System Final

I Safety Analysis Report (Van Keuren 1996a, Van Keuren 1996b). This methodology converts a volume of waste material into radiological and toxicological consequences. The GOTH computer model provides data in mass units. Volume units are derived through simple conversions based on the assumptions listed in Table 1.

The mitigative effect of cover blocks is calculated by the ratio of expected tank bump aerosol loading to the theoretical maximum aerosol loading.

Preventative measures are based on interpolation of historical data.

\subsection{ASSUMPTIONS}

\subsection{Tank Waste}

The tank headspace is assumed to be air with a quantity of aerosolized aging waste liquids entrained in it-due to aerodynamic re-suspension. A partition fraction of $10^{-8}$ is considered bounding (Voice 1994). The entire headspace volume is assumed to be displacedvented during the tank bump event. 
WHC-SD-WM-CN-043, Rev. 2

Table 1. Tank 101-AZ Waste Parameters (Sathya 1996).

Tank Contents:

Undissolved (dry) Solids Density

$243.41 \mathrm{bm} / \mathrm{ft}^{3}$

Aqueous Solution Density

$75.51 \mathrm{bm} / \mathrm{ft}^{3}$

Saturation temperature of the 1 iquid waste is $110^{\circ} \mathrm{C}\left(230^{\circ} \mathrm{F}\right)$ at atmospheric pressure and increases with increased hydrostatic head (Sathya 1993). To calculate the effects of hydrostatic head on the saturation temperature, the waste density is conservatively assumed to match water(i.e., a minimal density yields a lower bound on the hydrostatic head).

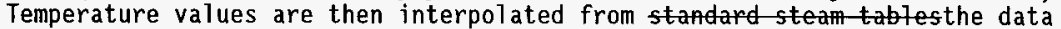
presented in Sathya (1993).

Tank waste is assumed to heat up linearly with time upon loss of active ventilation. This is conservative in that the rate of heat loss from the tank to the soil is expected to increases as the temperature increases, that is, the rate of temperature rise decreases with increasing temperature.

Therefore, the rate of temperature rise at a particular temperature is bounded by a linear interpolation of lower temperature data. In addition, review of temperature data from the 1992 ventilation outage in tank 24l-C-106 indicates that sludge temperature response is well represented by a linear model while headspace temperature response is not (Bander 1995).

\subsection{GOTH Model}

The GOTH computer analysis modeled the tank as a sealed container with two openings in order to model the ventilation system header and the infiltration pathways. Both openings were assumed to be simple risers open to atmospheric pressure with a particular loss coefficient. The infiltration pathways opening was assumed to be located at the center of the tank while the vent header opening was set off center. Several different sizes of these openings were considered in order to simulate the different possible tank configurations (e.g., pump/sluice pits with and without cover blocks).

The release quantities provided by the GOTH computer model had two distinct components. The first component is the release due to fluid dynamics; that is, the event produced fluid velocities such that the waste is carried out the open riser due to momentum. The second component is the release due to pressurization effects; that is, the tank headspace pressure becomes positive with respect to atmospheric which forces waste out of the tank to a region of lower pressure. In reality, the tank risers are covered with either equipment (e.g., pumps) or flanges that are bolted in place. The only pathway is through the pit drain lines. These lines come into the main risers at a $90^{\circ}$ angle and include another $90^{\circ}$ bend between the riser and the pit. Because of these two bends, very little of the fluid dynamic portion of the release willis actually expedimpact the piping and be severely reduced if not eliminated. Inclusion of fluid dynamics, therefore, is conservative. 
WHC-SD-WM-CN-043, Rev. 2

As expected, most of the simulated bumps occurred in the center of the tank. The highest fluid velocities are produced directly above the tank bump. Therefore, most of the calculated releases include a strong fluid dynamic contributor. One simulation, however, resulted in a bump that was slightly off-center. Because the high fluid velocities were not directly under a release path for this simulation the fluid dynamic portion of the release was I significantly reduced. This result (case 2 of Sathya 1996) matches actual tank configuration closely and was, therefore, used for consequence calculations.

\subsection{Mitigation}

The maximum concentration of entrained liquid in a vapor is assumed to be $1 \mathrm{~g} / \mathrm{m}^{3}$. This is two orders of magnitude more conservative than the metastable concentration of a fog $\left(10 \mathrm{mg} / \mathrm{m}^{3}\right)$ but is consistent with the liquid water content in natural clouds (Sutter 1982).

Cover blocks are assumed to affect the liquid and solid aerosols entrained in the escaping steam. The escaping steam is assumed to be pure water vapor that provides liquid and solid aerosol transport but contains no other radioactive or toxic constituents. Headspace gas and water vapor is assumed to travel around cover blocks unimpeded.

\subsection{Accident Frequency}

The expected frequency of a tank bump in 241-AZ-101 is assumed to be "unlikely". This frequency is based on the postulated initiating event and the slow heat up rate. Given current tank 241-AZ-101 waste conditions, a ventilation outage of approximately 90 days duration would be required for steam generation to commence (Sathya 1996). Extreme conditions would be necessary to cause such an extended outage. The most frequent event judged to be capable of producing such extreme conditions is an earthquake that caused widespread damage such that the ventilation system was rendered inoperable and repair crews were assigned elsewhere.

\subsection{INPUT DATA}

The GOTH model used in consequence calculations set the infiltration pathways to a single riser equivalent to five risers, each with a four inch diameter and the ventilation header to 20 inches. This simulation provided the output shown in Table 2 .

\begin{tabular}{|l|c|}
\hline \multicolumn{2}{|c|}{ Table 2. Waste Released by GOTH Model (Sathya 1996). } \\
\hline Vapor Released & $7401 \mathrm{bm}$ \\
\hline Respirable Liquid Released & $561 \mathrm{bm}$ \\
\hline Respirable Solids Released & $11 \mathrm{bm}$ \\
\hline
\end{tabular}


WHC-SD-WM-CN-043, Rev. 2

For approximately 5 months (160 days) at the beginning of 1992 the active ventilation system for $241-C-106$ was inoperable. During this period the peak temperature rose from about $68^{\circ} \mathrm{C}\left(155^{\circ} \mathrm{F}\right)$ to $92^{\circ} \mathrm{C}\left(197^{\circ} \mathrm{F}\right)$. The heat load estimate for this tank is 32,200 W (110,000 BTU/h) (Kummerer 1995).

\subsection{CALCULATIONS}

\subsection{Unmitigated Consequences}

Consequences are calculated by summing up the consequences of three components: gasheadspace aerosols, respirable liquid, and respirable solids. The gasheadspace volume of 241-AZ-101, and therefore the aerosol volume, is taken to be a fixed $1,900 \mathrm{~m}^{3}$ (Hodgson 1996). This is based on the assumption that the entire headspace volume will be displace by the tank bump presure transient. The liquid and solid quantities are based on the values in Table 2 and converted with the assumptions in Table 1 .

5.1.l Radiological. Onsite-nadiological dose calculations are found with the following equation (Van Kueren 1996a).

$$
\text { Dose }=(V)\left[\frac{X}{Q}\right](B R)(U L D)
$$

where:

$V=$ Volume of waste released

$X / Q_{\text {onsite }}=$ Atmospheric dispersion coefficient $=3.41 \times 10^{-2} \mathrm{~s} / \mathrm{m}^{3}$

$B R=$ Breathing Rate $=3.3 \times 10^{-4} \mathrm{~m}^{3} / \mathrm{s}$

ULD inhale, Liquid $=$ Unit Liter Dose $=1.4 \times 10^{3} \mathrm{~Sv} / \mathrm{L}$

ULD inhale, solids $=1.7 \times 10^{6} \mathrm{~Sv} / \mathrm{L}$

\section{| 5.1.1.1 Onsite}

\section{therefore}

The volume of liquid waste aerosolized in the tank headspace is found by multiplying the headspace volume by the partition fraction (PF). The associated onsite radiological dose can then be found as a function of the liquid waste content. 


$$
\begin{aligned}
& \text { WHC-SD-WM-CN-043, Rev. } 2 \\
& V_{\text {gas }}=\left(1900 \mathrm{~m}^{3} \text { gas }\right)\left(1000 \frac{L}{\mathrm{~m}^{3}}\right]\left[\frac{10^{-8} L \text { liquid }}{L \text { gas }}\right] \\
&=1.9 \times 10^{-2} \mathrm{~L} \text { liquid } \\
& D_{\text {gas onsite }}=\left(1.9 \times 10^{-2} \mathrm{~L} \text { liquid }\right)\left[3.41 \times 10^{-2} \frac{\mathrm{s}}{\mathrm{m}^{3}}\right)\left[3.3 \times 10^{-4} \frac{\mathrm{m}^{3}}{\mathrm{~s}}\right)\left(1400 \frac{\mathrm{sv}}{\text { L liquid }}\right) \\
&=3.0 \times 10^{-4} \mathrm{sv}
\end{aligned}
$$

I The onsite radiological dose associated with the liquid release is

$$
\begin{aligned}
V_{\text {liquid }} & =\left(\frac{567 \mathrm{bm} \text { liquid }}{75.5 \frac{7 b \mathrm{~m}}{f t^{3}}}\right)\left(28.3 \frac{\mathrm{L}}{\mathrm{ft}^{3}}\right) \\
& =21.0 \mathrm{~L} \text { liquid } \\
D_{\text {liquid onsite }} & =(21.0 \mathrm{~L} \text { liquid })\left[3.41 \times 10^{-2} \frac{\mathrm{s}}{\mathrm{m}^{3}}\right)\left[3.3 \times 10^{-4} \frac{\mathrm{m}^{3}}{\mathrm{~s}}\right]\left(1400 \frac{\mathrm{sV}}{\mathrm{L} \text { liquid }}\right) \\
& =3.3 \times 10^{-1} \mathrm{sv}
\end{aligned}
$$

The onsite radiological dose associated with the respirable solids release is

$$
\begin{aligned}
V_{\text {solid }} & =\left(\frac{1 \mathrm{lbm} \text { solid }}{243.4 \frac{\mathrm{lbm}}{f t^{3}}}\right)\left[28.3 \frac{\mathrm{L}}{\mathrm{ft}}\right) \\
& =0.12 \mathrm{~L} \mathrm{solid} \\
D_{\text {solid onsite }} & =(0.12 \mathrm{~L} \mathrm{solid})\left[3.41 \times 10^{-2} \frac{\mathrm{s}}{\mathrm{m}^{3}}\right)\left[3.3 \times 10^{-4} \frac{\mathrm{m}^{3}}{\mathrm{~s}}\right)\left(1.7 \times 10^{6} \frac{\mathrm{sV}}{\mathrm{Lsolid}}\right) \\
& =2.2 \mathrm{sV}
\end{aligned}
$$




\subsubsection{Offsite}

The offsite dose is found similarly but includes an ingestion term and an Theriate X/Q (Van Kueren 1996a).

$$
\text { Dose }=(V)\left[\frac{X}{Q}\right]_{\text {offsite }}\left[(B R)\left(U L D_{\text {inhale }}\right)+U L D_{\text {ingest }}\right]
$$

where:

$$
\begin{array}{ll}
X / Q_{\text {offsite }} & =2.83 \times 10^{-5} \mathrm{~s} / \mathrm{m}^{3} \\
U L D_{\text {ingest, liquid }} & =0.092 \mathrm{~Sv}^{3} / \mathrm{s} \mathrm{L} \\
U L D_{\text {ingest, sol id }} & =8.1 \mathrm{SV} \mathrm{m}^{3} / \mathrm{s} \mathrm{L}
\end{array}
$$

therefore

$$
\begin{aligned}
& D_{\text {gas offsite }}=\left(1.9 \times 10^{-2} \text { L liquid }\right)\left[2.83 \times 10^{-5} \frac{\mathrm{s}}{\mathrm{m}^{3}}\right] \\
& {\left[\left(3.3 \times 10^{-4} \frac{\mathrm{m}^{3}}{\mathrm{~s}}\right]\left[1400 \frac{\mathrm{sv}}{\text { L liquid }}\right]+\left[0.092 \frac{\mathrm{sv} \mathrm{m^{3 }}}{\mathrm{sL}}\right)\right]} \\
& =3.0 \times 10^{-7} \mathrm{~Sv} \\
& D_{\text {liquid offsite }}=(21.0 \mathrm{~L} \text { liquid })\left(2.83 \times 10^{-5} \frac{\mathrm{s}}{\mathrm{m}^{3}}\right) \\
& {\left[\left(3.3 \times 10^{-4} \frac{\mathrm{m}^{3}}{\mathrm{~s}}\right)\left[1400 \frac{\mathrm{sV}}{\text { L liquid }}\right]+\left[0.092 \frac{\mathrm{sV} \mathrm{m^{3 }}}{\mathrm{sL}}\right)\right]} \\
& =3.3 \times 10^{-4} \mathrm{~Sv}
\end{aligned}
$$


WHC-SD-WM-CN-043, Rev. 2

$$
\begin{aligned}
& D_{\text {solid offsite }}=(0.12 L \text { solid })\left[2.83 \times 10^{-5} \frac{\mathrm{s}}{\mathrm{m}^{3}}\right] \\
& {\left[\left(3.3 \times 10^{-4} \frac{\mathrm{m}^{3}}{\mathrm{~s}}\right]\left[1.7 \times 10^{6} \frac{\mathrm{sv}}{\mathrm{Ls0lid}}\right)+\left[8.1 \frac{s v \mathrm{~m}^{3}}{\mathrm{~s} L}\right]\right]} \\
& =1.9 \times 10^{-3} \mathrm{SV}
\end{aligned}
$$

The results are summarized in Table 3 .

Table 3. Unmitigated Radiological Consequences.

\begin{tabular}{|l|c|c|}
\hline & Onsite & 0ffsite \\
\hline Gas Dose & $3.0 \mathrm{E}-04 \mathrm{~Sv}$ & $3.0 \mathrm{E}-07 \mathrm{SV}$ \\
\hline Liquid Dose & $3.3 \mathrm{E}-01 \mathrm{SV}$ & $3.3 \mathrm{E}-04 \mathrm{SV}$ \\
\hline Solids Dose & $2.2 \mathrm{E}+00 \mathrm{~Sv}$ & $1.9 \mathrm{E}-03 \mathrm{~Sv}$ \\
\hline \hline Total Dose & $2.5 \mathrm{E}+00 \mathrm{SV}$ & $2.2 \mathrm{E}-03 \mathrm{SV}$ \\
\hline
\end{tabular}

5.1.2 Toxicological. Toxicological consequences fop shopt duration events such as the tank bump-are found by multiplying the total quantity released by the appropriate sum-of-fractions (SOF) number (Van Keuren 1996b). The tank bump model predicted steam generation and release lasting approximately 80 seconds with liquid and solid particles being ejected during the first second (Sathya 1996). Because the released steam is assumed to be uncontaminated, the release that leads to toxicological consequences occurs in less than 3.5 seconds; therefore, the release is taken to be a puff.

The result is a normalized consequence, i.e., values greater than one indicate consequences above evaluation guidelines. The values chosen and the results are presented in Table 4.

\subsection{Cover Block Decontamination Factor}

If the cover blocks are not in place then the escaping waste is released directly to the atmosphere. The cover blocks act as a stagnation plate to the escaping waste stream and promote liquid rain out. Steam enters the pump or sluice pits with a high liquid density $\left(\gg 1 \mathrm{~g} / \mathrm{m}^{3}\right)$ and forces any existing air out. The pressure in a given pit then rises until the steam flow into the pit equates to the flow out of the pit. Flow out of the pit is limited to a liquid loading of $1 \mathrm{~g} / \mathrm{m}^{3}$. That is, 1 iquid will remain entrained in the steam until the entrained liquid density in the pit volume reaches the maximum (1) $\left.\mathrm{g} / \mathrm{m}^{3}\right)$. At that point the excess liquid will rain out and drain back to the 
WHC-SD-WM-CN-043, Rev. 2

tank. The ratio of the entrained liquid ando the maximum entrained liquid is the decontamination factor.

Table 4. Unmitigated Toxicological Consequences

\begin{tabular}{|l|c|c|c|}
\hline & Quantity & Un7ikely Puff SOF & Consequence \\
\hline \hline \multicolumn{4}{|c|}{ Onsite } \\
\hline Gas & $1,900 \mathrm{~m}^{3}$ & $2.8 \pm 1009.9 \mathrm{E}-02 / \mathrm{m}^{3}$ & $5.3 E+031.9 \mathrm{E}+02$ \\
\hline Liquid & $21 \mathrm{~L}$ & $2.2 \mathrm{E}+02 / \mathrm{L}$ & $4.6 \mathrm{E}+03$ \\
\hline Solids & $0.1 \mathrm{~L}$ & $9.7 \mathrm{E}+02 / \mathrm{L}$ & $9.7 \mathrm{E}+01$ \\
\hline Sum Tota1 & \multicolumn{4}{|c|}{ Offsite } & $1.044 .9 \mathrm{E}+03$ \\
\hline \hline \multicolumn{5}{|c|}{} \\
\hline Gas & $1,900 \mathrm{~m}^{3}$ & $9.2 \mathrm{E}-06 / \mathrm{m}^{3}$ & $1.7 \mathrm{E}-02$ \\
\hline Liquid & $21 \mathrm{~L}$ & $3.4 \mathrm{E}-02 / \mathrm{L}$ & $7.1 \mathrm{E}-01$ \\
\hline Solids & $0.1 \mathrm{~L}$ & $5.9 \mathrm{E}-02 / \mathrm{L}$ & $5.9 \mathrm{E}-03$ \\
\hline Sum Tota7 & & $7.3 \mathrm{E}-01$ \\
\hline
\end{tabular}

Steam enters the sealed pump and sluice pits at an average pressure of $15 \mathrm{psia}$. The specific volume of this steam is, therefore, $26.29 \mathrm{ft}^{3} / 1 \mathrm{~b}$ (saturated steam at $15 \mathrm{psia}$ ). GOTH indicates that $7401 \mathrm{bm}$ of steam is released over 80 seconds. The rate of steam release is givencan be calculated by

$$
\dot{v}_{\text {steam }}\left(\frac{f t^{3}}{s}\right)=\frac{m_{\text {steam }}(7 b m) v_{\text {steam }}\left(\frac{f t^{3}}{7 b m}\right)}{t(s)}
$$

GOTH also indicates that $561 \mathrm{bm}$ of tank liquid is released over the same duration. The rate of liquid release is givencan be calculated by

$$
\dot{m}_{\text {liquid }}\left[\frac{7 \mathrm{bm}}{\mathrm{s}}\right]=\frac{m_{\text {liquid }}(\mathrm{lbm})}{t(\mathrm{~s})}
$$


WHC-SD-WM-CN-043, Rev. 2

The mass loading of liquid in the steam is given by

$$
\rho\left(\frac{l b m \text { liquid }}{f t^{3} \text { steam }}\right)=\frac{\dot{m}_{\text {liquid }}\left(\frac{7 b m}{s}\right)}{\dot{V}_{\text {steam }}\left(\frac{f t^{3}}{s}\right)}
$$

The decontamination factor is then

$$
D F=\frac{\rho\left(\frac{1 b m \text { liquid }}{f t^{3} \text { steam }}\right)}{1\left(\frac{\text { g liquid }}{m^{3} \text { vapor }}\right)}
$$

DF is found to be 46 . The numeric calculations are in appendix $A$.

It is recognized that the decontamination factor is actually a transient value which would be quite high near the beginning of a bump event and low near the end. The integrated and averaged quantities (Sathya 1996) are used to provide a representation of the entire event.

\subsection{Mitigated Consequences}

Mitigated consequences are calculated the same way as unmitigated consequences except that the liquid and solids waste quantities are reduced by the decontamination factor. That is,

$$
V_{\text {mitigated }}=\frac{V_{\text {released }}}{D F}
$$

5.3.1 Radiological: The mitigated radiological consequences are summarized in Table 5 .

5.3.2 Toxicological. The mitigated toxicological consequences are summarized in Table 6 . 
WHC-SD-WM-CN-043, Rev. 2

Table 5. Mitigated Radiological Consequences.

\begin{tabular}{|l|c|c|c|}
\hline & Quantity & Onsite Dose & Offsite Dose \\
\hline Gas & $1,900 \mathrm{~m}^{3}$ & $3.0 \mathrm{E}-04 \mathrm{~Sv}$ & $3.0 \mathrm{E}-07 \mathrm{~Sv}$ \\
\hline Liquid & $0.46 \mathrm{~L}$ & $7.4 \mathrm{E}-03 \mathrm{~Sv}$ & $7.2 \mathrm{E}-06 \mathrm{SV}$ \\
\hline Solids & $2.5 \mathrm{E}-03 \mathrm{~L}$ & $4.8 \mathrm{E}-02 \mathrm{~Sv}$ & $4.1 \mathrm{E}-05 \mathrm{~Sv}$ \\
\hline Sum Total & $5.6 \mathrm{E}-02 \mathrm{SV}$ & $4.9 \mathrm{E}-05 \mathrm{SV}$ \\
\hline
\end{tabular}

Table 6. Mitigated Toxicological Consequences

\begin{tabular}{|l|c|c|c|}
\hline & Quantity & Onsite & 0ffsite \\
\hline Gas & $1,900 \mathrm{~m}^{3}$ & $5.3 \mathrm{E}+031.9 \mathrm{E}+02$ & $1.7 \mathrm{E}-02$ \\
\hline Liquid & $0.46 \mathrm{~L}$ & $1.0 \mathrm{E}+02$ & $1.5 \mathrm{E}-02$ \\
\hline Solid & $2.5 \mathrm{E}-03 \mathrm{~L}$ & $2.4 \mathrm{E}+00$ & $1.3 \mathrm{E}-04$ \\
\hline Sum Total & & $5.4 \mathrm{E}+032.9 \mathrm{E}+02$ & $3.2 \mathrm{E}-02$ \\
\hline
\end{tabular}

\subsection{Rate of Temperature Rise}

The data provided by the ventilation outage at 241-C-106 during the beginning of 1992 can be applied to all SSTs by the ratio of the respective heat loads. This can be justified in that all SSTs have similar configuration and soil characteristics and, therefore, eject heat virtually identically to one another. The application is accomplishedA first order estimate is provided by establishing a temperature rise constant that can be multiplied by the tank heat generation rate.

$$
\dot{T}=k \cdot H G R
$$

Thermocouple accuracy is $\pm 5^{\circ} \mathrm{F}$; therefore, to calculate a bounding value for the temperature rise constant this error is added to the measured temperature values. 
WHC-SD-WM-CN-043, Rev. 2

$$
\begin{aligned}
k & =\frac{\left(\frac{T_{\max }-T_{\text {initial }}}{t_{\text {outage }}}\right)}{H G R_{C-106}}=\frac{\left(\frac{202^{\circ} \mathrm{F}-150^{\circ} \mathrm{F}}{160 \text { day }}\right)}{110,000 \frac{B T U}{h}} \\
& =3 \times 10^{-6} \frac{{ }^{\circ} \mathrm{F}}{\frac{B T U}{h} \cdot d a y}
\end{aligned}
$$

Table 7 lists several tanks and their calculated rate of temperature rise from this method.

Table 7. Rate of Temperature Rise For Selected Single-Shell Tanks

\begin{tabular}{|c|c|c|c|}
\hline \multirow{2}{*}{ Tank } & $\begin{array}{c}\text { Heat Load } \\
\text { (Kummerer 1995) }\end{array}$ & $\begin{array}{c}\text { Rate of } \\
\text { Temperature Rise }\end{array}$ & $\begin{array}{c}\text { Time Required to Raise } \\
\text { Temperature } 10^{\circ} \mathrm{F}\end{array}$ \\
\cline { 2 - 4 } & BTU/h & ${ }^{\circ} \mathrm{F} /$ day & days \\
\hline \hline C-106 & 110,000 & 0.33 & 125 \\
\hline SX-103 & 27,742 & 0.08 & 63 \\
\hline SX-107 & 54,779 & 0.16 & 59 \\
\hline SX-108 & 55,983 & 0.17 & 111 \\
\hline SX-109 & 31,035 & 0.09 & 83 \\
\hline$S X-110$ & 40,767 & 0.12 & 56 \\
\hline$S X-111$ & 61,013 & 0.18 & 83 \\
\hline$S X-112$ & 41,594 & 0.12 & 56 \\
\hline$S X-114$ & 58,692 & 0.18 & 80 \\
\hline
\end{tabular}

Tank 241-AZ-101 has been calculated to heat up at approximately $0.5^{\circ} \mathrm{C} /$ day $\left(0.9^{\circ} \mathrm{F} /\right.$ day) (Sathya 1994$)$. This tank is bounding for all DSTs because its heat load is double that of any other DST. 
WHC-SD-WM-CN-043, Rev. 2

\subsection{RESULTS}

\subsection{Consequences}

offsite consequences are below risk guidelines for all cases. However, onsite consequences are above risk guidelines for all cases. These results are summarized in Table 8.

Table 8. Comparison of Consequences to Risk Guidelines.

\begin{tabular}{|l|c|c|c|}
\hline & $\begin{array}{c}\text { Unmitigated } \\
\text { Consequence }\end{array}$ & $\begin{array}{c}\text { Mitigated } \\
\text { Consequence }\end{array}$ & $\begin{array}{c}\text { Risk } \\
\text { Guidelines }\end{array}$ \\
\hline Onsite Radiological & $250 \mathrm{Rem}$ & $5.6 \mathrm{Rem}$ & $5 \mathrm{Rem}$ \\
\hline Offsite Radiological & $0.22 \mathrm{Rem}$ & $4.9 \mathrm{E}-03 \mathrm{Rem}$ & $0.5 \mathrm{Rem}$ \\
\hline Onsite Toxicological & $1.0 \mathrm{E}+044.9 \mathrm{E}+03$ & $5.4 \mathrm{E}+032.9 \mathrm{E}+02$ & 1 \\
\hline Offsite Toxicological & 0.73 & $3.2 \mathrm{E}-02$ & 1 \\
\hline
\end{tabular}

\subsection{SST Temperature Limit}

Based on the information presented in Table 7, it would conservatively take tank 241-C-106 (the bounding case) approximately 30 days to raise from $99^{\circ} \mathrm{C}\left(210^{\circ} \mathrm{F}\right)$ to $104^{\circ}\left(220^{\circ} \mathrm{F}\right)$ upon a loss of active ventilation. The other SSTs would take considerably longer. Therefore, assuming a temperature limit of $99^{\circ} \mathrm{C}\left(210^{\circ} \mathrm{F}\right)$ allows approximately one month to take corrective action upon a system upset before significant steam generation would occur.

\subsection{DST Temperature Limits}

Based on the calculated heat up of tank $241-A Z-101\left(0.9^{\circ} \mathrm{F} /\right.$ day $)$, it would take approximately 25 days for the tank temperature to increase $12^{\circ} \mathrm{C}\left(20^{\circ} \mathrm{F}\right)$. Therefore, in order to allow approximately one month to take corrective action upon a system upset (the same time span specified for the SSTs) a temperature limit of $93^{\circ} \mathrm{C}\left(200^{\circ} \mathrm{F}\right)$ must be assumed. Most DSTs also contain a large

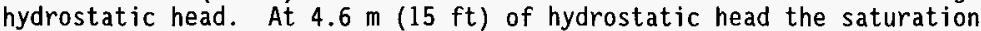
temperature increases approximately $12^{\circ} \mathrm{C}\left(20^{\circ} \mathrm{F}\right)$. Therefore, a higher allowable temperature of $104^{\circ} \mathrm{C}\left(220^{\circ} \mathrm{F}\right)$ can be assumed at waste depths greater than $4.6 \mathrm{~m}(15 \mathrm{ft})$.

\subsection{CONCLUSION}

Cover blocks are an effective mitigator but are not sufficient by themselves to adequately protect the onsite worker. The only way to bring consequences below risk guidelines is to prevent the tank bump. 
WHC-SD-WM-CN-043, Rev. 2

Prevention of the tank bump can be accomplished by maintaining waste temperatures below the local saturation temperature of the liquid waste. If the waste is not allowed to saturate then no steam can form and the event is prevented.

\subsection{REFERENCES}

Bander, T. J., 1995, Tank 241-C-106 Process Test Report, WHC-SD-WM-ER-427, Rev. 0, Westinghouse Hanford Company, Richland, Washington.

Hodgson, K. M., Anantatmula, R. P., Barker, S. A., Fowler, K. D., Hopkins, J. D., Lechelt, J. A., Reynolds, D. A., Hedengren, D. C., Stout, R. E., Winward, R. T., 1996, Evaluation of Hanford Tanks for Trapped Gas, WHC-SD-WM-ER-526, Rev. 1, Westinghouse Hanford Company, Richland, Washington.

Kummerer, M., 1995, Heat Removal Characteristics of Waste Storage Tanks, WHC-SD-WM-SARR-010, Rev. 1, Westinghouse Hanford Company, Rich1 and, Washington.

Sathyanarayana, K., Fryer, B. C., Thurgood, M. J., 1994, Summary Report: Thermal Hydraulic Safety Analysis of Aging Waste Tank 101-AZ, WHC-SD-WM-ER-335, West inghouse Hanford Company, Richland, Washington.

Sathyanarayana, K., Fryer, B. C., 1996, Evaluation of Potential and Consequences of Steam Bump in High Heat Waste Tanks and Assessment and Validation of GOTH Computer Code, WHC-SD-WM-CN-022, Westinghouse Hanford Company, Richland, Washington.

Sathyanarayana, K., Thurgood, M. J., Fryer, B. C., 1993, Development of a Dynamic Computer Simulator for Aging Waste Tank Operation and Safety Assessment, WHC-SD-WM-ER-198, West inghouse Hanford Company, Rich1 and, Washington.

Sutter, S. L., 1982, Accident Generated Particulate materials and Their Characteristics -- A Review of Background Information, NUREG/CR-2651, PNL-4154, Pacific Northwest Laboratory, Rich1and, Washington.

Van Keuren, 1996a, Tank Waste Compositions and Atmospheric Dispersion Coefficients for Use in Safety Analysis Consequence Assessments, WHC-SDWM-SARR-016, Rev. 2, Westinghouse Hanford Company, Rich1and, Washington.

Van Keuren, J. C., Davis, J. S., Dentler, M. L., 1996b, Toxic Chemical Considerations for Tank Farm Releases, WHC-SD-WM-SARR-011, Rev. 2, Westinghouse Hanford Company, Richland, Washington.

Voice, J. D., 1994, Tank Farm Accelerated Safety Analysis: Tank Ventilation Systems, WHC-SD-WM-SARR-018, Westinghouse Hanford Company, Rich 1 and, Washington. 
WHC-SD-WM-CN-043, Rev. 2

\section{APPENDIX A - Decontamination Factor Calculations}




\section{Decontamination Effect of Pump Pit Cover Blocks on Tank Bump Release}

Calculations performed by Mathematica for Windows*- Standard Version 2.2

\section{Initialize for English/Metric Conversions}

$<$ Miscellaneous 'Units'

\section{Code Verification}

Please Note: The command "SI[expr]" converts units to the SI system.

SI [ 1 Pound]

0.45359237 Kilogram

SI [1 Foot^3]

0.0283168 Meter

SI [1 Pound/Foot^3]

$16.0185 \mathrm{Kilogram}$

Meter

\section{Assumptions}

Please Note: The semicolon following a command suppresses output.

maxDensity=1 Gram/Meter^3 (liquid/steam) ;

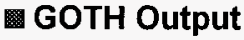

averageAbsolutePressure=15 PoundForce/Inch^2;

steamDensity=1/26.29 Pound/Foot^3;

liquidReleased=56 Pound liquid;

steamReleased $=740$ Pound steam;

solidReleased $=1$ Pound solid;

bumpDuration $=80$ second;

Windows is a trademark of Hicrosoft Corporation. 
WHC-SD-WM-CN-043, Rev. 2

\section{Calculations}

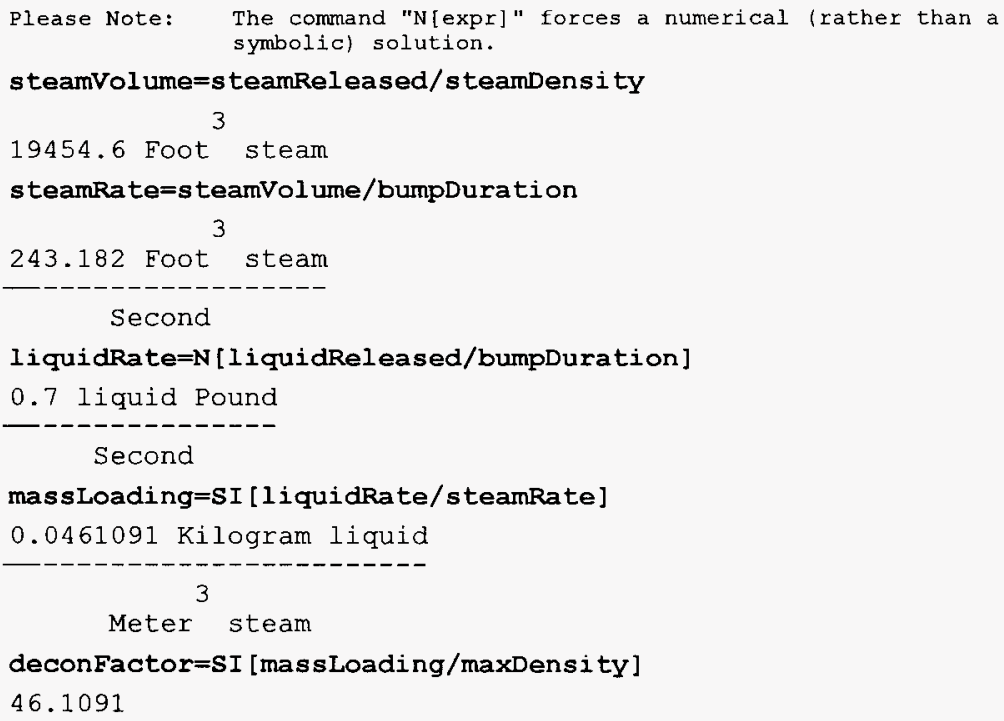


WHC-SD-WM-CN-043, Rev. 2

CHECKLIST FOR PEER REVIEW

Document Reviewed: Tank Bump Consequence Analys is, WHC-SD-WM-CN-043, Rev. 2

Scope of Review: Entire Document

Yes No NA

[メ] [ ] [ ] * Previous reviews complete and cover analysis, up to scope of this review, with no gaps.

$[x][$ ] [ ] Problem completely defined.

¿] [ ] [ ] Accident scenarios developed in a clear and logical manner.

[] [ ] [ ] Necessary assumptions explicitly stated and supported.

[] [ ] f ] Computer codes and data files documented.

X] [ ] [ ] Data used in calculations explicitly stated in document.

D] [ ] [ ] Data checked for consistency with original source information as applicable.

[ ] [ ] $[$ ] Mathematical derivations checked including dimensional consistency of results.

[ ] [ ] $₫$ Models appropriate and used within range of validity or use outside range of established validity justified.

$\bowtie$ [ ] [ ] Hand calculations checked for errors. Spreadsheet results should be treated exactly the same as hand calculations.

[ ] [ ] [ Software input correct and consistent with document reviewed.

[ ] [ ] $]$ Software output consistent with input and with results reported in document reviewed.

$\nVdash[$ [ ] ] Limits/criteria/guidelines applied to analysis results are appropriate and referenced. Limits/criteria/guidelines checked against references.

$\bowtie[$ [ [ ] Safety margins consistent with good engineering practices.

[X] [ ] [ ] Conclusions consistent with analytical results and applicable limits.

[ [ ] [ ] Results and conclusions address all points required in the problem statement.

M [ ] [ ] Format consistent with appropriate NRC Regulatory Guide or other standards

[ ] $X *$ Review calculations, comments, and/or notes are attached.

$\mathbb{X}[\mathrm{b}]$, Document approved.

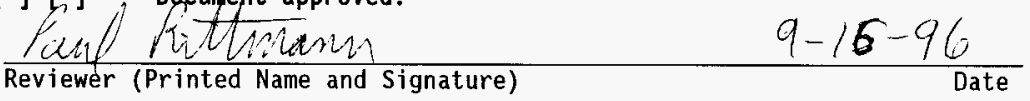

* Any calculations, comments, or notes generated as part of this review should be signed, dated and attached to this checklist. Such material should be labeled and recorded in such a manner as to be intelligible to a technically

qualified third party.
heut uf calculations are based on of and then converted to ${ }^{\circ} \mathrm{C}$ - 